\title{
Transitivity Analysis of Kamala Harris' 2020 Presidential Victory Speech Concerning COVID-19
}

\author{
Alfath Eka Liani*, Annisa Annidi, Yanty Wirza \\ English Language Education, Universitas Pendidikan Indonesia, Bandung \\ ${ }^{*}$ Corresponding author. Email: alfathekalianii@gmail.com
}

\begin{abstract}
Language plays a vital role in political speech as it comes in a form of argument shaping and speech presenting which often contain a set of beliefs called ideology. It gets even more crucial when the speech is delivered as a presidential victory speech from developed countries such as the USA. Hence, investigation regarding presidential victory speech should be conducted. Regarding this, the present study aims to investigate the presence of political ideology in the USA 2020 vice president-elect Kamala Harris' victory speech concerning her plans to build back the USA during the COVID19 pandemic. This is due to the fact that not only she is the first female vice-president elect but she is also representing the people of colour. This study employs Qualitative Content Analysis (QCA) as the research method with Halliday's transitivity system as the framework to analyse the data. The result shows that Kamala Harris implicitly demonstrates her liberalism ideology by inviting all the American people to not only focus on their own liberty but also others as well through the utilisation of Material (60\%), Relational (19\%), Mental (11\%) and Behavioural (3\%) processes in her speech. Thus, in other words, Kamala Harris plans to build back the USA by starting to enforce people's liberty.
\end{abstract}

Keywords: COVID-19, Kamala Harris, liberalism, political speech, transitivity system

\section{INTRODUCTION}

Language is crucially vital when it comes to any form of general communication as it is the tool for exchanging information (Martin, 2015). However, in the world of politics, Beard (2000), Dhanianti (2014) and Guswita (2020) mention that language plays a more fundamental role as it is utilised in politicians' argument shaping and speech presenting which often contain a set of beliefs that are commonly known as ideology. Moreover, political speech is usually delivered as a form of communication with the general public that is aimed to gather votes during presidential elections, or to gather support during presidential victory speech (Fairclough, 1989; Krizsán, 2013; Liao, 2019).

In regards of presidential victory speech, van Dijk (2006) and Reeve (2017) argue that most of the time, that specific type of speech does not only encompass the president- and vice presidents-elect's ideology but also structural patterns that help them convincing and persuading the general public to support them as the new president and vice president. In addition to this, Argina (2018) further adds that presidential victory speech could also predict the likeliness of how it will affect their success in years to come. Hence, it is fundamental to investigate presidential victory speech in regard to critically examining it, especially when it comes to speeches that are delivered by president- and vice president-elect from Super Power countries such as the USA (Arisetiayani \& Yuliasry, 2017; Ulum, Sutopo, \& Warsono, 2018)

\subsection{USA's Political Ideology and COVID-19}

Historically, ideology has been long defined as a concept, a value and even a set of beliefs that is perceived as imaginary ideas which are related to the ideational conspiracy of a group of people who have the same goal (Erikson \& Tedin, 2003; Jost, Glaser, Kruglanski, \& Sulloway, 2003; McLellan, 1986). In terms of political ideology, Freeden (2001) as well as Shook and Fazio (2009) state that it is related to the concept of positive and negative aspects, resulting in differences of how language is conveyed in politics.

When it comes to the USA, the majority of the people believe in the ideology of liberalism (Fiorina, Abrams, \& Pope, 2010; McCarty, Poole, \& Rosenthal, 2016). This indicates that most Americans adhere Mill's principles of ideology in which one's actions, as far as they affect the needs of no one except himself, that individual is not 
liable to society for his acts. Yet, for those actions that are adverse to the interests of others, that individual is accountable and may be subjected to social or legal retribution if society determines that one or the other is appropriate for its safety (Mill \& Rapaport, 1978).

The USA has just had the 2020 presidential election in which Joe Biden and Kamala Harris are becoming the president- and vice president-elect. This not only gains a tremendous amount of attention from the people of America but also the entire world because Kamala Harris is the first ever female from people of colour community that becomes the USA's vice president-elect. Besides, her policy which would be implemented could also affect other countries' politics and economy as well (Krizsán, 2013). Moreover, according to Lipscy (2020) as well as Zhifa, Xiaohan, and Yanhong (2020), the current situation of newly known COVID-19 pandemic is still rising significantly in the USA. Thus, resulting in her presidential victory speech regarding how she would handle the situation would also be the focus for the world to discuss.

Acknowledging this, the inquirers are aware that Kamala Harris' victory speech should be investigated as she would deliver plans to handle COVID-19 pandemic situation which never happened before. Also, her speech may contain implicit ideology, specifically the ideology of liberalism which relates to her roles as a person of colour. As for the investigation of her speech, the inquirers would employ Systemic Functional Linguistics (SFL) framework, which is Halliday's (1985) transitivity system.

\subsection{Halliday's Transitivity System}

According to Martin (2015) and Halliday (1981), SFL perceives languages as systems that are able to break down and elaborate the construction of language in terms of its usefulness, one of which is through transitivity system. This system is able to elaborate and encode what is going on in society as opposed to the traditional grammar into three classifications, namely Process, Participant and Circumstance (Emilia, 2014). Regarding the former term, it further comprises six categories: Material process, Mental process, Relational process, Behavioural process, Verbal process and Existential process (Halliday, 1985).

In relation to political speeches, several previous studies concerning those are known to be investigated using Halliday's transitivity system. For instance, Zhang (2017) investigates Donald Trump's and Hillary Clinton's first television debate in regard to uncovering the distribution of Processes, Participants and Circumstances types that were mostly used by them. The result shows that Trump used more Existential processes while Clinton used more Material processes, indicating that they have different approaches to the people.
Another similar research is also conducted by Liao (2019) who focuses on examining Xi Jinping's and Donald Trump's inaugural speeches in terms of their Process types. He reports that while Xi Jinping utilised more Material, Mental and Relational processes to showcase his concern for social advancement and economic situation in China, Trump utilised more of those processes to gain more support from the American people. Furthermore, Adjei and Ewusi-mensah (2016) in their analysis of Kufour's farewell speech, found out that Kufour used more Material process and almost used no Behavioural process in his political speech delivered to the Ghanaian parliament, suggesting that he viewed the world in terms of his present and past experiences only. On the other hand, Agbo, Ngwoke and Ijem's (2019) study concerning President Buhari's "My Covenant with Nigerians" speech reports that President Buhari utilised more of Mental and Verbal processes in order to display his commitment to serve Nigerians.

Acknowledging those previous research studies successfully uncover obscure meaning in political speeches through transitivity analysis, the inquirers decided to employ Halliday's transitivity framework to find out whether or not a particular political ideology appears in the vice president-elect Kamala Harris' victory speech concerning the plan to build back the USA during COVID-19 pandemic.

\section{METHOD}

To investigate the presence of political ideology in Kamala Harris' victory speech concerning the plan to build back the USA during COVID-19 pandemic, this study is conducted under the qualitative paradigm with Qualitative Content Analysis (QCA) as the method. QCA is utilised due to the fact that it is concerned with the notion of "cracking the codes" of the content being examined using a specific analysis framework which transforms the coded analysis into a more comprehensive elaboration (Babbie, 2001). In relation to this study, the content being investigated is Kamala Harris's victory speech while the coding framework used is Halliday's transitivity system. Additionally, Hsieh and Shannon (2005) mention that QCA is related to highlighting textual data in order to reveal the emerging themes of the text. Hence, QCA is considered to be the appropriate method used in this study as it helps the inquirers accomplish the aim of this study.

The content being explored in this study is a political speech delivered by Kamala Harris during her presidential 2020 victory speech as Joe Biden's vice president-elect. Concerning the content being examined is in a form of video file, thus, the video is taken from the USA TODAY's YouTube (2020, 00:00-03:18). In the specificity of the video, Kamala Harris' victory speech is chosen due to the reason that people often centre more on the president-elect's victory speech and only little 
attention is given to the vice presidents-elect. Moreover, the content delivered is focused on the plan to build back the USA during COVID-19 pandemic which is a heated conversation among Americans. Therefore, the speech is chosen to be further examined in order to shed lights on the future of American people.

In order to answer the research questions of this study, the data collection technique employed in this study is to collect and analyse Kamala Harris' 2020 presidential victory speech using Halliday's transitivity system. The video of Kamala Harris' victory speech is transcribed and then segmented into sentences and clauses in order to make it easier to be analysed. Those sentences and clauses are chunked into several categories of Processes and Participant types which are further counted and examined. Table 1 and Table 2 below are the examples of Kamala Harris' speech analysis using the transitivity framework.

Table 1 Analysis of Kamala Harris' victory speech (1)

\begin{tabular}{lll}
\hline Actor & Pr: & Goal \\
& Material & \\
\hline $\begin{array}{l}\text { President- } \\
\text { elect Biden } \\
\text { and I }\end{array}$ & just met & $\begin{array}{l}\text { with some of our } \\
\text { nation's business and } \\
\end{array}$ \\
\end{tabular}

Table 2 Analysis of Kamala Harris' victory speech (2)

\begin{tabular}{|c|c|c|c|}
\hline & Value & $\begin{array}{l}\text { Pr: } \\
\text { Intensive }\end{array}$ & Token \\
\hline Together, & they & represent & $\begin{array}{l}\text { millions of } \\
\text { workers } \\
\text { [[across our } \\
\text { country]] } \\
\text { Circ: Location } \\
\text { and some of } \\
\text { America's } \\
\text { leading } \\
\text { technology, } \\
\text { auto, and retail } \\
\text { companies }\end{array}$ \\
\hline
\end{tabular}

\section{FINDINGS AND DISCUSSION}

The analysis of vice president-elect Kamala Harris' victory speech begins with chunking the transcription into sentences and clauses in order to classify each type of processes, namely Material, Mental, Verbal, Relational, Behavioural and Existential processes. Those processes are calculated based on the frequency of their occurrence in the speech in order to find out the implicit ideology behind her and the president-elect Joe Biden's plan to rebuild back USA's economy during the COVID19 pandemic. It could be seen in Figure 1 that the majority of the processes recorded in Kamala Harris' speech is Material processes $(60 \%)$, followed by Relational (19\%) and Mental processes (11\%) respectively. However, Figure 1 also displays that the least type of processes presented in Kamala Harris speech are Behavioural processes $(3 \%)$ and there is no Existential process recorded at all.

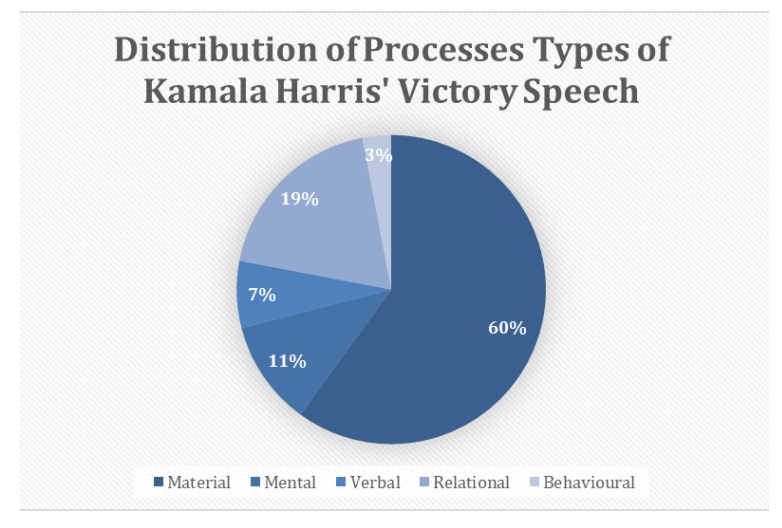

Figure 1 Transitivity distributions in Kamala Harris' speech

Figure 1 displays that the majority of transitivity processes that appear in Kamala Harris' speech is Material process which takes $60 \%$ of the total speech. Material process is the process of doing which gives a representation of actions that occur within the speech. This indicates that Kamala Harris, as a vice president alongside the president-elect Biden, acts as an active agent who concentrates on providing social action that aims to improve the welfare of the American people during the Covid-19 pandemic. Furthermore, the dominance of this type of processes reveals not only Kamala Harris plans to rebuild the USA back during the pandemic, but also showcase her concern and what the critical issues are that the American face. Below are some of the Materials processes found in Kamala Harris' speech:

- "President-Elect Biden and I just met with some of our nation's business and union leaders." (sample \#1)

- "We have also had a conversation about the impact this pandemic has had on our economy as a whole" (sample \#2)

- "... (front liners) who have risked their own health and the health of their families and the health of their families, and many whom have given their own lives to keep us safe and keep our economy running." (sample \#3)

- "...we will do it by protecting the health and safety of our workers and creating millions of good-paying union jobs..." (sample \#4)

- "The president-elect and I are focused on building our country back better for them (front liners) and all Americans." (sample \#5) 
Sample \#1, \#2 and \#3 further demonstrate that the Material processes are linked to how Kamala Harris is aware and concerned about the current situation by informing that she acknowledges COVID-19 has put front liners at risk and even lost their life, and that she had discussed things related to how to cope with that situation. This indicates that, since things have been discussed, chances are, she could come up with good solutions in handling the current situation which later shown in sample \#4 and \#5. Therefore, the Material process in her speech has given confidence and has assured the people that Kamala Harris could really provide solutions for them. Moreover, this finding is aligned with the result of studies conducted by Zhang (2017), Liao (2019), as well as Adjei and Ewusi-mensah (2016) who reveal that the Material processes in political speech are dominantly utilised to show the politicians' concern for the situation that is currently faced by their countries.

In regard to the implicit ideology in Kamala Harris' speech, she also uses Material processes to implicitly show the ideology of liberalism that she holds as well as represents the overall American ideology as it could be seen in sample \#6. Furthermore, another implicit liberalism ideology appears when she puts emphasis on her speech which is specifically aimed for the people of colour especially the black communities as shown in sample \#7:

- "...the good work of getting this virus under control, saving lives, and beating this pandemic and opening our economy responsibly" (sample \#6)

- "...This pandemic and this recession have hit communities of colour particularly hard." (sample \#7)

In sample \#6, Kamala Harris uses "opening" as the Material process followed by "our economy responsibly". This line means that she makes sure that the people could do their pre-pandemic activity by allowing the people to go to work so that they could sustain their life "responsibly" by respecting the principles of liberty proposed by Mill:

"One's actions, as far as they affect the needs of no one except himself, that individual is not liable to society for his acts. Yet for those actions that are opposed to the interests of others, that individual is accountable and may be subjected to social or legal retribution if society determines that one or the other is appropriate for its safety." (Mill \& Rapaport, 1978)

In other words, Kamala Harris is forcing the people of America to respect other people's liberty that is to be free from catching the virus from the infected ones. Here, her idea is to allow them to go back to work but with new emergency work regulations which require them to wear masks, maintain social distancing, wash their hands with soap regularly and sanitise themselves. Furthermore, this indicates that, for those who do not go back to work responsibly, chances are, they would be detained since trespassing other people's liberty which is not to catch the disease is considered as an act of crime.

Moreover, the statement given in sample \#7 displays that Kamala Harris is well aware of the tension happening between the black community and the white supremacists, thus, she wants to express that she does care by bringing that issue up in her speech. This relates to the BLM protest which was triggered by the killing of George Floyd and later caused massive rage in the black community. BLM protest in the USA is concerned with equality and equity law enforcement issues in which for the most part, black communities in the USA face many racial judgements and different treatment especially during this pandemic such as higher unemployment rates and different access to medical health facilities (Béland, Dinan, Rocco, \& Waddan, 2020; Bureau of Labor Statistics, 2020; Korhonen \& Granberg, 2020). In other words, the BLM movement seeks to find freedom of justice for its people of colour. Hence, that particular line in Kamala Harris' speech implicitly shows her liberalism side to also raise awareness concerning the idea of racial freedom or liberty, in this case is freedom for the black community to be treated equally and receive equal access to public health facilities.

As for the Relational processes which are the second most used type of processes (19\%) in Kamala Harris' speech, it relates to connecting an entity or activity with other entities or activities. For Instance, in Kamala Harris's speech, she uses the words "is" and "are" quite a lot. These demonstrate the relationship, the impact and the relational identification of the problems faced by the American people during the COVID-19 pandemic as shown in sample \#8, \#9 and \#10:

- "Black Americans and Latinos are three times as likely to contract COVID as others and more likely to die" (sample \#8)

- "Native Americans are more than four times as likely to be hospitalized as others.” (sample \#9)

- "...the unemployment rate for Black Americans was almost twice the rate of others." (sample \#10)

The use of Relational processes in Kamala Harris' statement as displayed in sample \#8, \#9 and \#10 further strengthen her concerns regarding the issues that are faced by the community of people of colour, specifically black communities as demonstrated in sample \#7 previously. It could be seen that she uses Relational processes to present facts regarding the impact of the pandemic that are faced by the people of colour as well as convince the American people that that specific community do not receive any equal treatment as they should be during the pandemic (see sample \#10). This is aligned with the utilisation of Relational processes found in Liao (2019) study in which he reveals that both $\mathrm{Xi}$ 
Jinping and Donald Trump mostly used Relational processes to showcase their concern related to their countries' economic situation and social advancement. In relation to this study, hence, it could be concluded that Kamala Harris does not only use Material processes to implicitly deliver her liberalism ideology, but she also uses the Relational processes to raise awareness among the American people that the people of colour also deserve equal liberty which is not to be restricted from accessing the same facilities whether it is to work or to receive health care services.

The Mental processes was found in Kamala Harris' speech up to $11 \%$ of the overall percentages, and she mostly utilises them to further display her sympathy and concern toward the people that are greatly impacted by the current pandemic situation. She acknowledges that the current pandemic has caused them to not only lose their jobs but also to risk and even lose their life. The example of the utilisation of mental processes in her speech could be seen in sample \#11, \#12 and \#13:

- "Over the past few months on the campaign trail, the president-elect and I saw that impact first-hand." (sample \#11)

- "...many others who have had to close their doors and fear never reopening at all.” (sample \#12)

- "The American people deserve no less." (sample \#13)

It could be seen that the utilisation of the Mental processes in sample \#11, \#12 and \#13 are intended to show sympathy as well as shared feelings that Kamala Harris has for the people that are greatly impacted by COVID-19. This implies that she is trying to convince the American people that she acknowledges what exactly the impacts are and that she has well-thought plans in order to handle those impacts. Concerning this, similar previous study conducted by Agbo et al. (2019) also uncover that Mental processes are in fact, commonly used to display a politician's plans and commitment to serve for his or her country. For instance, President Buhari on his "My Covenant with Nigerians" speech, utilises this process to show his commitment to serve the Nigerians (Agbo et al., 2019).

As for the liberalism ideology, it is implicitly delivered by her in sample \#12 in which she mentions that some Americans are experiencing fear of not getting back to work due to the high rates of COVID-19 cases. This corresponds to her statement in sample \#6 that the people could go back to work only if they do it responsibly. In other words, sample \#12 means that some Americans feel their liberty to be COVID-19 free are threatened due to the fact that there are still irresponsible Americans out there who steal their liberty by not following the obligatory emergency law. Saying this, Kamala Harris tries to assure and raise awareness that liberty in terms of being free from other people' irresponsible behaviour, is one of the aspects that should be enforced during this pandemic. Additionally, her statement in sample \#13 further asserts that all Americans deserve the same rights and same liberty to build back their normal life during the pandemic. Hence, if all Americans could respect this aspect of liberty, this would result in not only the enforcement of people's security but also the increase of their economic condition which leads to the betterment of the USA.

In terms of the Behavioural processes which only take about $3 \%$ of the overall process types, Kamala Harris uses that to strengthen her concern about the impact of COVID-19 in sample \#3 and \#12. An example of Behavioural processes found in her speech is shown in sample \#14:

- “...even as they worry about their family's wellbeing and their own." (sample \#14)

Sample \#14 further asserts the idea of people experiencing their liberty taken away from them. This means, Mill's principle of liberty should be enforced and implemented in regard to secure people's liberty and not violating it.

To sum up, in delivering her speech, Kamala Harris mostly uses Material, Relational and Mental processes to not only convince the American people on how she would build back their nation together based on facts and data, but also to sympathise, raise awareness and enforce people's liberty in receiving the same level of both equality and equity especially for those in the people of colour community and black community. Therefore, as a politician and a vice president-elect, it could be concluded that Kamala Harris does apply her title to implicitly deliver her liberalism ideology that she holds in order to build back the USA by focusing on the enforcement of its people's liberty.

\section{CONCLUSION}

This study is conducted in regard to examining the presence of political ideology in vice president-elect Kamala Harris' victory speech concerning the plan to build back the USA during COVID-19 pandemic through the utilisation of Halliday's transitivity system. After thorough investigation, it is revealed that the majority of Kamala Harris' speech is dominated with Material processes $(60 \%)$ followed by Relational processes (19\%) and Mental processes (11\%) respectively. Moreover, there is only a little percentage shown for the presence of Behavioural processes (3\%). It is discovered that Kamala Harris mixes all the above types of processes in order to not only show her and Biden's plan to build back the USA during the pandemic, but also to show sympathy, raise awareness and enforce people's liberty especially those who are from people of colour community and black community. In other words, Kamala Harris implicitly presents her liberalism ideology that she holds 
in which she invites all the American people to not only focus on their own liberty but also others as well. This means that if one's liberty is being misunderstood which later leads to damaging others' liberty, then they are being irresponsible and may be restrained or detained for breaking one's liberty.

\section{REFERENCES}

Adjei, A. A., \& Ewusi-Mensah, L. (2016). Transitivity in Kufour's 2008 farewell speech to the Ghanaian parliament. British Journal of English Linguistics, 4(1), 36-49. Retrieved from https://www.eajournals.org/journals/britishjournal-of-english-linguistics-bjel/

Agbo, I. I., Ngwoke, F. U., \& Ijem, B. U. (2019). Transitivity processes in president Buhari's 'My covenant with Nigerians'. English Language Teaching, 12(4), 7-14. https://doi.org/10.5539/elt.v12n4p7

Argina, A. W. (2018). Presupposition and campaign rhetoric, a comparative analysis of Trump and Hillary's first campaign speech. International Journal of English and Literature, 8(3), 1-14. https://doi.org/10.24247/ijeljun20181

Arisetyarani, Y., \& Yuliasry, L. (2017). Observance of Cialdini's principles of speech act of persuasion in 2016 US presidential debates. English Education Journal, $\quad 7(3), \quad 237-246$. https://doi.org/10.15294/EEJ.V7I3.20742

Babbie, E. (2007). The practice of social research (11th ed.). Belmont, CA: Thomson Wadsworth.

Beard, A. (2000). The language of politics. Routledge. Retrieved from https://www.routledge.com/TheLanguage-of-

Politics/Beard/p/book/9780415201780

Béland, D., Dinan, S., Rocco, P., \& Waddan, A. (2020). Social policy responses to COVID-19 in Canada and the United States: Explaining policy variations between two liberal welfare state regimes. Social Policy \& Administration, 1-15. https://doi.org/10.1111/spol.12656

Bureau of Labor Statistics. (2020, June). The employment situation - June 2020. Retrieved from https://www.bls.gov/news.release/pdf/empsit.pdf

Dhanianti, R. (2014). Transitivity on analysis Barack Obama victory speech. Retrieved from http://eprints.dinus.ac.id/8308/

Emilia, E. (2014). Introducing functional grammar. Bandung, Indonesia: Dunia Pustaka Jaya.
Erikson, R. S., \& Tedin, K. L. (2003). American public opinion: Its origins, content, and impact (6th ed.). New York, NY: Longman.

Fairclough, N. (1989). Language and power. London, UK: Longman.

Fiorina, M. P., Abrams, S. J., \& Pope, J. C. (2010). Culture war? The myth of a polarized America (3rd ed.). New York, NY: Longman.

Freeden, M. (2001). Reassessing political ideologies: The durability of dissent (1st ed.). New York, NY: Routledge.

Guswita, K. A. (2020). Transitivity analysis of Jokowi and Prabowo campaign speech in Indonesian presidential election. Indonesian Journal of EFL and Linguistics, 5(1), 143-158. Retrieved from http://indonesian-efl-

journal.org/index.php/ijefll/article/view/234

Halliday, M. A. K. (1981). Explorations in the function of language. London, UK: Edward Arnold.

Halliday, M. A. K. (1985). An introduction to functional linguistics. London, UK: Edward Arnold.

Hsieh, H.-F., \& Shannon, S. E. (2005). Three approaches to qualitative content analysis. Qualitative Health Research, 15(9), 1277-1288. https://doi.org/10.1177/1049732305276687

Jost, J. T., Glaser, J., Kruglanski, A. W., \& Sulloway, F. J. (2003). Political conservatism as motivated social cognition. Psychological Bulletin, 129(3), 339-375. https://doi.org/10.1037/0033-2909.129.3.339

Korhonen, J., \& Granberg, B. (2020). Sweden backcasting, now? - strategic planning for Covid19 mitigation in a liberal democracy. Sustainability, 12(10), 4138-4153. https://doi.org/10.3390/su12104138

Krizsán, A. (2013). Ideologically speaking. Pragmatics and Society, 4(2), 177-199. https://doi.org/10.1075/ps.4.2.04kri

Liao, G., \& Han, G. (2019). Ideological differences between America and China from perspectives of transitivity system - illustrated by Trump's and Xi Jinping's presidential inaugural addresses. Journal of Language Teaching and Research, 10(4), 800806. https://doi.org/10.17507/jltr.1004.16

Lipscy, P. Y. (2020). COVID-19 and the politics of crisis. International Organization Online Supplement, 74, 1-30. https://doi.org/10.1017/S002081832000037

Martin, J. R. (2015). Cohesion and texture. In D. Tannen, H. E. Hamilton, \& D. Schiffrin (Eds.), Handbook of discourse analysis (2nd ed., pp. 61-81). John Wiley. https://doi.org/10.1002/9781118584194 
McCarty, N., Poole, K. T., \& Rosenthal, H. (2016). Polarized America: The dance of ideology and unequal riches (2nd ed.). London, UK: The MIT Press.

McLellan, D. (1986). Ideology. University of Minnesota Press.

Mill, J. S., \& Rapaport, E. (1978). On liberty (8th ed.). Indianapolis, Indiana: Hackett Publishing Company.

Reeve, C. D. C. (2017). Politics: A new translation (the new Hackett Aristotle). Indianapolis, Indiana: Hackett Publishing Company.

Shook, N. J., \& Fazio, R. H. (2009). Political ideology, exploration of novel stimuli, and attitude formation. Journal of Experimental Social Psychology, 45(4), 995-998.

https://doi.org/10.1016/j.jesp.2009.04.003

Ulum, M., Sutopo, D., \& Warsono, W. (2018). A comparison between Trump's and Clinton's commissive speech act in America's presidential campaign speech. English Education Journal, 8(2), 221-228. https://doi.org/10.15294/EEJ.V8I3.21391

USA TODAY. (2020, November 17). President-elect Joe Biden delivers remarks on the economy [Video file]. Retrieved from https://youtu.be/TcJNE-3iVp0

van Dijk, T. A. (2006). Ideology and discourse analysis. Journal of Political Ideologies, 11(2), 115-140. https://doi.org/10.1080/13569310600687908

Zhang, Y. (2017). Transitivity analysis of Hillary Clinton's and Donald Trump's first television debate. International Journal of Applied Linguistics and English Literature, 6(7), 65-72. https://doi.org/10.7575/aiac.ijalel.v.6n.7p.65

Zhifa, Z., Xiaohan, T., \& Yanhong, L. (2020). The crisis of global COVID-19 governance and the challenge of liberalism from error-tolerantism. Philosophy Study, 10(9), 544-557. https://doi.org/10.17265/2159-5313/2020.09.005 